\title{
Neodymium and Strontium isotopes as source indicators for terrigenous sediments deposited in NE Brazil
}

\author{
Itxaso Ruiz(1) and Leopoldo Pena ${ }^{(2)}$ \\ (1) Basque Centre for Climate Change (BC3), Scientific Campus of the University of the Basque Country, Spain \\ (2) Department of Earth and Ocean Dynamics, University of Barcelona, Spain \\ itxaso.ruiz@bc3research.org
}

\begin{abstract}
This study investigates the sedimentary origin of materials deposited by the Amazon River over the last 30 kyr BP and reconstructs the precipitation pattern of the source area at the time of the erosion. For this purpose, fifteen samples of a down-core sediment record from the French Guiana margin have been used to analyse neodymium (Nd) and strontium $(\mathrm{Sr})$ isotope ratios. The sample results $(\mathrm{Sr}$ : $0.71385 \pm 0.00166$; $\left.\varepsilon_{\mathrm{Nd}}:-11.67 \pm 0.55\right)$ suggest that the western Amazon basin catchment area is the main source of the terrigenous material, and point to the Solimões river basin as the most probable origin. This study also discusses the strong coherence between the registered millennial events and the atmospheric settings of the region, which indicate humid land conditions for the Heinrich Stadials 1 and 2 compared to the Last Glacial Maximum, and during the Last Glacial Maximum compared to the early Holocene.
\end{abstract}

Keywords: Neodymium (Nd), paleoclimate, sedimentary basin, source, Strontium (Sr).

\section{Isótopos de Neodimio y Estroncio como indicadores del área fuente del material terrígeno depositado en el NE de Brasil}

\section{RESUMEN}

Este estudio investiga el origen sedimentario de los materiales depositados por el río Amazonas durante los últimos $30 \mathrm{kyr} B P$ y reconstruye el patrón de precipitación del área fuente. Para ello, se han utilizado quince muestras de un registro sedimentario marino ubicado en el margen de la Guayana Francesa y se han analizado los isótopos de Neodimio (Nd) y de Estroncio (Sr). Los resultados (Sr: 0.71385 $\pm 0.00166 ; \varepsilon_{N d}:-11.67 \pm 0.55$ ) sugieren que la zona del Amazonas occidental es la fuente principal del material terrígeno, y apuntan a la cuenca del río Solimões como el origen más probable. Así mismo, el análisis paleoclimático de la zona refuerza esta conclusión, exhibiendo condiciones continentales húmedas para los Heinrich Stadials 1 y 2 en comparación con el Último Máximo Glacial, así como para el Último Máximo Glacial en comparación con el Holoceno temprano.

Palabras clave: Cuenca sedimentaria, Estroncio (Sr), fuente, Neodimio (Nd), paleoclima.

\section{VERSIÓN ABREVIADA EN CASTELLANO}

\section{Introducción y metodología}

Este estudio analiza la influencia del gradiente de temperatura tierra-océano en el régimen de precipitación de la cuenca amazónica occidental para el Holoceno y Pleistoceno tardío. Para ello, mostramos datos isotópicos de Estroncio (Sr), junto con isótopos de Neodimio (Nd) obtenidos para las mismas muestras y publicados anteriormente por Zhang et al. (2015). Además de las interpretaciones paleoclimáticas, se analiza el origen y la proveniencia de los sedimentos recogidos. Este análisis es posible debido al potencial de los elementos de las tierras raras (REEs) para trazar composiciones de área fuente y a su conservación frente a procesos sedimentarios posteriores. 
I. Ruiz and L. Pena, 2018. Neodymium and Strontium isotopes as source indicators for... Boletín Geológico y Minero, 129 (4): $633-646$

La importancia de asignar el área fuente de sedimentos depositados por el río Amazonas se basa en su ciclo del agua transformado, puesto que su alteración ha inducido graves consecuencias socioeconómicas en los últimos años.

Los resultados de Sr aquí presentados, corresponden al testigo GeoB16224-1 (6 $\left.6^{\circ} 39.38^{\prime} \mathrm{N} / 52^{\circ} 04.99^{\prime} \mathrm{W}\right)$, obtenido en la campaña oceanográfica RV Maria S. Merian MSM20/3 (Mulitza et al., 2013). GeoB16224-1 es un testigo cilíndrico de $760 \mathrm{~cm}$ de longitud que cubre aproximadamente los últimos 30 kyr (miles de años) $B P$ y se encuentra en el talud continental de la Guayana Francesa, a 2510 m de profundidad (Figura 1). Su modelo de edad se basa en 10 análisis AMS de radiocarbono obtenidos a partir de foraminíferos planctónicos (Zhang et al., 2015) que fueron calibrados mediante la curva de calibración MARINE13 (Reimer et al., 2013) con el programa Calib 7.0 (Stuiver y Reimer, 1993). La edad asignada a cada muestra se ha interpolado linealmente con un error de $\pm 2 \sigma$ en la media.

Para la obtención de los resultados aquí expuestos, se realizó un ataque químico a las muestras y se procedió después a la recolección de $\mathrm{Sr}$ y $\mathrm{Nd}$. Para el ataque químico se disolvieron $0,8 \mathrm{~g}$ de cada muestra en $4 \mathrm{~mL}$ de $\mathrm{HF}_{\text {concentrado (conc) }}$ y $1 \mathrm{~mL}$ de $\mathrm{HNO}_{3 c o n c}$ en una relación 4:1. A continuación, se calentaron hasta $200{ }^{\circ} \mathrm{C}$ para obtener su completa disolución. Una vez secas, se repitió de nuevo el proceso. Posteriormente, para la disolución del tetrafluoruro de silicio se atacaron de nuevo con $0,5 \mathrm{~mL}$ de $\mathrm{HNO}_{3 \text { concr }}$ se secaron y se volvieron a atacar con $6 \mathrm{~mL}$ de $\mathrm{HCl}$ 6M. En última instancia y con el fin de reconvertir nitratos en $\mathrm{NO}_{3}$, las muestras fueron atacadas con $\mathrm{HNO}_{3}$. La recolección del Sr y del $\mathrm{Nd}$ se realizó mediante la preparación de las resinas de Sr y tierras raras (REEs), las cuales se usaron en tres columnas: a) Sr-SPEC, b) REE y c) LN. El Sr fue recogido de la primera columna, mientras que el Nd no se pudo aislar de las demás tierras raras y recoger hasta la tercera y última columna.

Tanto la preparación química de las muestras como la recolección de los datos isotópicos tuvieron lugar en la Universidad de São Paulo (USP) en el laboratorio del Centro de Pesquisas Geocronológicas (CPGeo). La adquisición de los datos se llevó a cabo utilizando multicolectores ICP-MS (Inductively Coupled Plasma-Mass Spectrometry) para el Nd y TIMS (Thermal lonization Mass Spectrometer) para el Sr. Se analizaron un total de 15 muestras, sumando 30 análisis isotópicos. El estándar analítico JNdi-1 dio valores de $0.512098 \pm 0.000006$ para el patrón ${ }^{143} \mathrm{Nd} /{ }^{144} \mathrm{Nd}(2 \sigma)$ y NBS-987 de $0.710264 \pm 0.000040(2 \sigma) \mathrm{para}^{87} \mathrm{Sr}{ }^{\beta 6} \mathrm{Sr}$.

\section{Resultados y conclusiones}

Los resultados obtenidos para los isótopos de ${ }^{87} \mathrm{Sr}{ }^{\beta 6} \mathrm{Sr}$ son de 0.712-0.716, mientras que los de $\varepsilon_{N d}$ publicados por Zhang et al. (2015) son de-12.22--11.11. Ambos isótopos exhiben valores notablemente constantes con una pequeña excursión de 0.003 para el Sr en el intervalo de tiempo 5.3-6 kry BP (Tabla 1). Dada la constancia isotópica del material analizado, se puede deducir que éste proviene de la misma área fuente. Además, la contribución eólica que se da en el talud continental de la Guayana Francesa se considera insignificante (Behling et al., 2000; Collins et al., 2013), resolvemos que éste es de origen fluvial. De esta forma asumimos que la totalidad de nuestra muestra ha sido transportada por el río Amazonas y no por los vientos alisios del Noreste, los cuales soplan desde el Océano Atlántico hacia el continente.

Los isótopos de Sr fueron analizados para la muestra total, sin diferenciación previa de la fracción de detritus. Sin embargo, la alta variabilidad en la relación de Sr (ver Kuznetsov et al., 2012) indica que la contribución de carbonatos marinos en la composición isotópica analizada es mínima. Así mismo, como las muestras tienen un origen común y han sido transportadas mediante los mismos procesos hidrológicos, inferimos que la posible alteración en la señal de Sr debido a procesos de fraccionamiento por tamaño de grano es escasa (ver Bouchez et al., 2011).

Para realizar la caracterización del área fuente, hemos comparado y contextualizado los resultados obtenidos con datos de la literatura (Goldstein et al., 1984; Rogers y Hawkesworth, 1989; Basu et al., 1990; van Schmus et al., 1995, 2011; Parra y Pujos, 1998; Viers et al., 2008) (Figura 2). El patrón isotópico considerado para ello distingue entre las tres provincias geotectónicas principales de la zona, siendo estas: la Cuenca Amazónica; la cordillera del Andes o rocas Andinas; y el Escudo Guayanés y rocas de Brasil central (Figura 3). Mientras que las rocas provenientes del Escudo Guayanés presentan valores isotópicos muy característi$\cos \operatorname{con} \varepsilon_{N d}(-29--23) y^{87} \mathrm{Sr}^{\beta 6} \mathrm{Sr}$ (1.7-2.7) (van Schmus et al., 1995), las rocas de la cuenca del Amazonas y de la cordillera del Andes registran valores de $\varepsilon_{N d}(-10-8.8)$ y $\varepsilon_{N d}(-14-13)$ respectivamente y de ${ }^{87} \mathrm{Sr}{ }^{\beta 6} \mathrm{Sr}(0.71-0.73)$ para ambos casos (Parra y Pujos, 1998; Viers et al., 2008). Las muestras aquí analizadas con valores de Sr alrededor de 0.71385 y valores de $\varepsilon_{N d}-11.67 \pm 0.55$, se aproximan a los del segundo grupo de muestras, confirmando que se tratan de sedimentos cuaternarios y terciarios que contienen una proporción significativa de corteza continental. Estas características isotópicas se dan en rocas que se encuentran en la cuenca Amazónica occidental, en donde se hallan las subcuencas hidrográficas de los ríos Solimões y Madeira (Fig. 1). Con el fin de desentrañar de cuál de las dos subcuencas proceden las muestras aquí analizadas, se han comparado una vez más los resultados obtenidos con datos de estudios previos (Viers et al., 2008; Bouchez 
I. Ruiz and L. Pena, 2018. Neodymium and Strontium isotopes as source indicators for... Boletín Geológico y Minero, 129 (4): $633-646$

et al., 2011; Horbe et al., 2014). De esta comparación se deduce que las muestras proceden de la cuenca del río Solimóes (Figura 4).

La correlación de estos resultados con el paleoclima continental de la zona Norte de Sudamérica es posible mediante su comparación con testigos marinos recuperados en la costa NE del Brasil (Jaeschke et al., 2007; Zhang et al., 2015), testigos de lagos glaciares de los Andes (Baker et al., 2001a, b) y espeleotemas de cuevas situadas en el Amazonas occidental (Wang et al., 2004; Kanner et al., 2012; Mosblech et al., 2012; Cheng et al., 2013) (ver Figura 5).

El ciclo hidrológico de la cuenca del Amazonas está estrechamente relacionado con el Monzón Sudamericano (SAM), con un patrón de lluvias acoplado a los períodos de insolación del verano austral (Baker y Fritz, 2015). Los datos de Sr aquí presentados se encuentran en sintonía con las características hidrográficas de la zona, mostrando valores altos y constantes de ${ }^{87} \mathrm{Sr}{ }^{\beta 6} \mathrm{Sr}$ para el Último Máximo Glacial (LGM) y para el Holoceno medio-tardío, que se atribuyen a una mayor erosión terrestre como consecuencia de un SAM más intenso, en donde la humedad atlántica tropical se recicla sobre la cuenca Amazónica. Así mismo, la relación ${ }^{87} \mathrm{Sr}{ }^{\beta 6} \mathrm{Sr}$ registra una fuerte caída (una diferencia de 0.033 de en el período 6-5.3 kry BP) coincidiendo con el inicio de la fase de baja insolación del verano austral.

Los distintos estudios mencionados anteriormente registran anomalías positivas de precipitación durante los Eventos Heinrich (HS) para casi toda la cuenca del Amazonas. Durante estos episodios abruptos, el gradiente de temperatura latitudinal del Atlántico se incrementa, resultando en un fortalecimiento de los vientos alisios del NE que desplazan la Zona de Convergencia Intertropical (ITCZ) hacia el sur y aportan mayor cantidad de humedad al SAM. Las consecuencias sobre el terreno de estos hechos, son el aumento de la precipitación, la erosión física y el transporte fluvial. Una vez más, nuestros resultados de Sr apuntan en la misma dirección para los eventos HS-1 y HS-2, indicando que estos dos eventos abruptos fueron asimismo húmedos. Este, sin embargo, no es el caso para el HS-3, que en conjunción con otros estudios de la zona (Mosblech et al., 2012; Cheng et al., 2013) muestra condiciones más secas, siendo ésta una de las dos excepciones, junto con el HS-6, al patrón abrupto y húmedo de los eventos Heinrich (Hemming, 2004).

Este estudio demuestra que es posible hallar el origen sedimentario de los materiales depositados por el río Amazonas mediante el análisis isotópico de Sr y Nd de las muestras.

\section{Introduction}

The study of past climate changes in the Amazon basin is feasible through the investigation of marine sediment cores due to their potential to trace past changes in the source areas that provide terrigenous sediment inputs into the ocean. Specifically, rare earth elements (REEs) are typically preserved during early sedimentary processes and hence, broadly correlated with the composition of a rock. In this way, measurements of neodymium ( $\mathrm{Nd}$ ) and strontium ( $\mathrm{Sr}$ ) radiogenic isotope ratios have been applied in a number of early (e.g. McLennan et al., 1984; Mearns, 1988) and more recent studies (e.g. Yang et al., 2007; Shao et al., 2015).

The importance of assigning terrigenous sediment sources within the Amazon drainage basin relies on its transformed water cycle, inducing severe socioeconomic consequences in recent years. On-land systems are the result of human interactions with the natural environment. Thus, it is of great importance to reconstruct and understand the paleoclimatic and paleohydrologic conditions of the Amazon basin, in order to better inform decision-makers about landuse planning, demand and supply of services and trade patterns.

This study focuses on the Holocene and late
Pleistocene climate history of the Amazon River and analyses the influence of the land-ocean temperature gradient in the precipitation regime of the western Amazon basin. To achieve this aim, we present novel $\mathrm{Sr}$ radiogenic isotope ratios and compare them with $\mathrm{Nd}$ data obtained for the same samples which were published by Zhang et al. (2015).

\section{Background: $\mathrm{Nd}$ and Sr isotopes}

The $\mathrm{Nd}$ isotope variability in the continents is closely related to crustal age, whereby the older continental crust has lower ${ }^{143} \mathrm{Nd} /{ }^{144} \mathrm{Nd}$ ratios than the younger continental crust and recent mantle-derived volcanic. The ${ }^{143} \mathrm{Nd} /{ }^{144} \mathrm{Nd}$ ratio is expressed as $\varepsilon_{\mathrm{Nd}}$, the deviation in parts per 10,000 from average chondrite (Jacobsen and Wasserburg, 1980). $\varepsilon_{\mathrm{Nd}}$ values show a global systematic geographic variability that mirrors the age of the continental crustal sources of $\mathrm{Nd}$. The decay of 147 Samarium ( ${ }^{147} \mathrm{Sm}$ : half-life of $106 \mathrm{Gyr}$ ) to ${ }^{143} \mathrm{Nd}$ allows $\mathrm{Nd}$ isotopic ratio $\left({ }^{143} \mathrm{Nd} /{ }^{144} \mathrm{Nd}\right)$ to be traced in long timescale geologic processes. Sm stays preferentially in the mantle during the formation of continental crust, therefore the abundance of ${ }^{143} \mathrm{Nd}$ in a rock varies as a function of age (i.e. $\mathrm{Sm} / \mathrm{Nd}$ ratio). That is, whilst a young crust is enriched in ${ }^{143} \mathrm{Nd}$ because the ${ }^{147} \mathrm{Sm}$ 
preferably stays in the mantle, the old crust becomes depleted on ${ }^{143} \mathrm{Nd}$ due to its active decay. Thus, $\mathrm{Nd}$ isotopic composition seems to be related to both lithology and tectonic diversity of source rocks, reflecting the radioactive decay of ${ }^{147} \mathrm{Sm}$ on Earth history (i.e. geological age of the source rock). In this way, Nd isotope ratio scan indicates the compositional provenance of sediments both in regional and local studies (McDaniel et al., 1997). Former studies of $\mathrm{Nd}$ isotopic systems provided important information both for understanding weathering processes as well as crustal evolution and composition (e.g. DePaolo and Wasserburg, 1976). ${ }^{143} \mathrm{Nd} /{ }^{144} \mathrm{Nd}$ are also reported for particulates from several rivers in the world, continental sediments and aeolian dusts collected over the Atlantic, Pacific, and Indian Oceans (e.g. Basu et al., 1990; McDaniel et al., 1997; Tassinari and Macambria, 1999). Additionally, they have been measured in terrestrial rock samples of different ages to establish the characteristics of $\mathrm{Nd}$ isotopic evolution in the crust and mantle.

Similarly, strontium $(\mathrm{Sr})$ isotope ratios $\left({ }^{87} \mathrm{Sr} /{ }^{86} \mathrm{Sr}\right)$ can be used as geochemical tracers of many continental processes, including soil genesis and biochemical cycling, surface-water and groundwater movement, weathering, paleohydrology of lakes, determination of marine versus freshwater deposition and lastly, stratigraphy of marine sediments (e.g. Gierlowski-Kordesch et al., 2008). Contrary to $\mathrm{Nd}, \mathrm{Sr}$ isotopes are fractionated by e.g. igneous processes, leading to the characterization of different igneous rocks. Hence, they have a lithological and tectonic dependency, in the sense that ${ }^{87} \mathrm{Sr} /{ }^{86} \mathrm{Sr}$ value tells how enriched or depleted its mantle source was. Previous studies have used $\mathrm{Sr}$ isotopes to trace provenances and pathways of suspended sediments as well as geochronological tectonic events (e.g. Allégre et al., 1996; Tassinari and Macambira, 1999; Weldeab et al., 2002; Gierlowski-Kordesch et al., 2008).

\section{Methodological approach}

\section{Regional setting}

In this study, we present unstable isotope values of $\mathrm{Sr}$ from site GeoB16224-1 (6 $\left.6^{\circ} 39.38^{\prime} \mathrm{N} / 5^{\circ} 04.99^{\prime} \mathrm{W}\right)$ retrieved during the RV Maria S. Merian cruise MSM20/3 (Mulitza et al., 2013). GeoB16224-1 is located at the continental slope off the French Guiana, at a depth of 2,510 m (Fig. 1). The main surface water current of the area is the north Brazil current (NBC), moving northward and fed by the south equatorial current (SEC) (Peterson and Stramma, 1991; Bourlès et al.
1999). The NBC is responsible for the majority of the transport of Amazon freshwater runoff and its terrigenous eroded sediments (e.g. Lentz, 1995; Allison et al., 2000). However, the tropical Atlantic has strong seasonal signals leading to variability in the NBC. In this way, the NBC is influenced by the wind-stress seasonal cycle; that is, by the NE trade winds. The NE trade winds are enhanced during cold seasons and/or events, when the latitudinal gradient of temperature of the Atlantic is higher, displacing the intertropical convergence zone (ITCZ) towards the south (see Richardson and Reverdin, 1987; Bourlès et al., 1999; Grodsky and Carton, 2002).

GeoB16224-1 is a $760 \mathrm{~cm}$ long gravity core that covers approximately the last $30 \mathrm{kyr}$ BP (late Pleistocene to the present). The age model for this site is based on 10 AMS radiocarbon analyses obtained from planktonic foraminifera (Zhang et al., 2015) and the resulting ages have been calibrated using the MARINE13 radiocarbon age calibration curve (Reimer et al., 2013) in the Calib 7.0 software (Stuiver and Reimer, 1993). The assigned age to each sample has been linearly interpolated with Matlab software, with a reported error of $\pm 2 \sigma$ on the mean.

\section{Analyses of the isotopic composition of $\mathrm{Nd}$ and $\mathrm{Sr}$}

Samples were dried for five days at $40{ }^{\circ} \mathrm{C}$ and then powdered. Meanwhile, the cleaning of all the necessary instruments and the preparation of the resins and blanks was carried out. For the chemical attack, $0.8 \mathrm{~g}$ of each sample was dissolved in $4 \mathrm{~mL}$ of HF concentrated (conc) and $1 \mathrm{~mL}$ of $\mathrm{HNO}_{3 \text { conc }}$ at $4: 1$. Subsequently, the sample was heated up to $110{ }^{\circ} \mathrm{C}$ for ten days. Samples were transferred to a calorimetric bomb for five more days and heated up at a temperature of $200{ }^{\circ} \mathrm{C}$, to achieve a better dissolution. The samples were then dried and attacked once more with $\mathrm{HF}_{\text {conc }}$ and $\mathrm{HNO}_{3 \text { conc }}$ For the dissolution of the silicon tetrafluoride, the samples were treated with $0.5 \mathrm{~mL}$ of $\mathrm{HNO}_{3 c o n c}$ and dried out. To obtain a complete dissolution, $6 \mathrm{~mL}$ of $\mathrm{HCl} 6 \mathrm{M}$ was added. Finally, the samples were attacked with $\mathrm{HNO}_{3}$. to reconvert the nitrates into a measurable $\mathrm{NO}_{3}$.

After the preparation of strontium and rare earth elements' (REEs) resins, $\mathrm{Sr}$ and $\mathrm{Nd}$ were collected following the next three steps: (1) Sr-SPEC column: the samples were dissolved in $1 \mathrm{~mL}$ of $\mathrm{HNO}_{3} 2 \mathrm{M}$ and strained through the resin. At this concentration, all the elements except $\mathrm{Sr}$-the so-called: matrix- were eluted and collected, since they do not have any affinity with it. Afterwards, $\mathrm{HNO}_{3} 0.5 \mathrm{M}$ was added, with the $\mathrm{Sr}$ being washed out this time, then collected and 


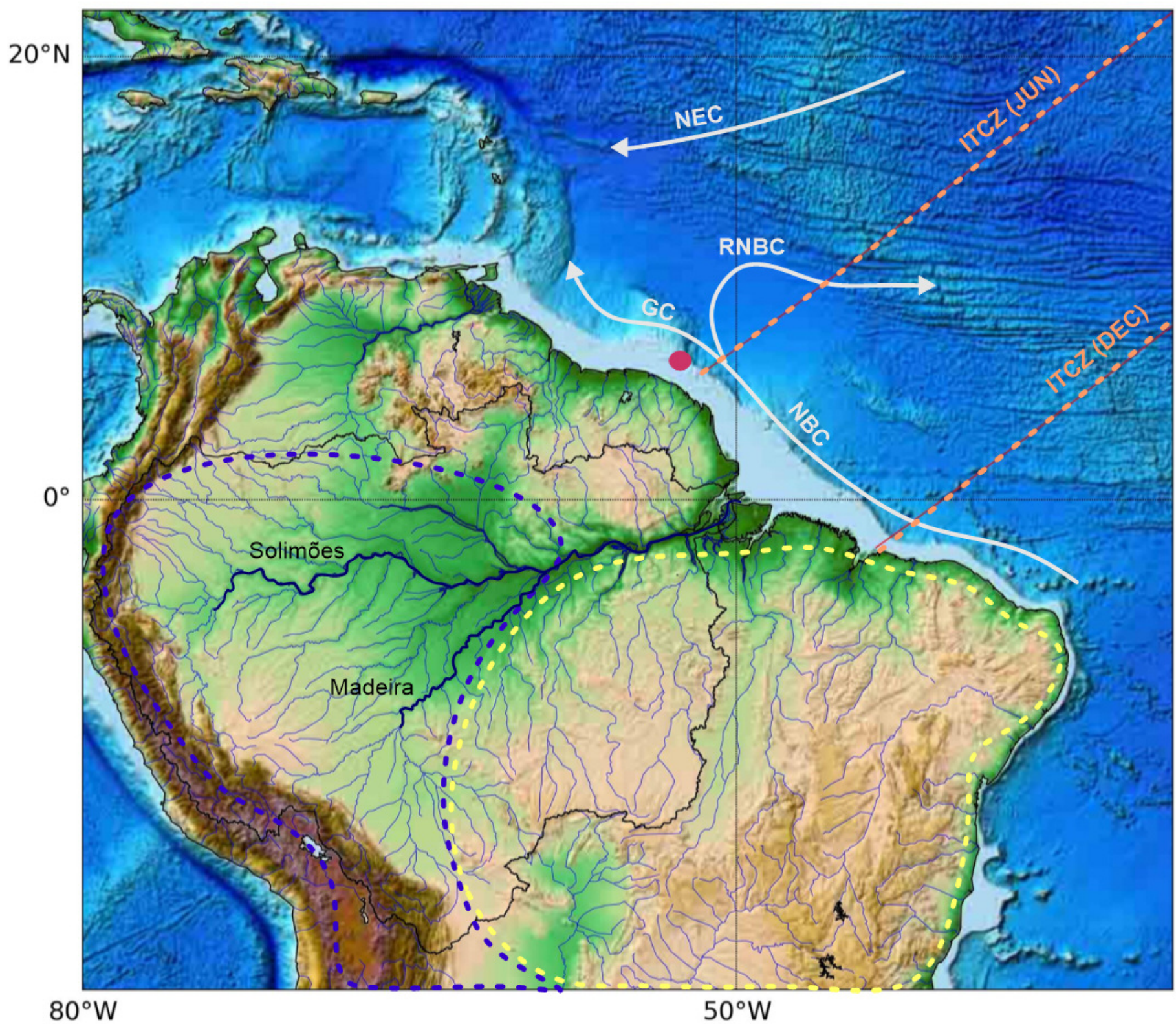

Figure 1. The Amazon basin with the Madeira and Solimões rivers, its climate patterns, and regional oceanic surface currents. The dot indicates the position of the core GeoB16224-1, on land dashed lines correspond to the South American Precipitation Dipole (SAPD), off land dashed lines correspond to the winter (Dec) and summer (Jun) positions of the ITCZ and solid arrows correspond to the surface regional currents: NEC: north equatorial current, GC: Guiana Current, NBC: north Brazilian current, RNBC: retroflection of the north Brazilian current. Source of information: Cheng et al., 2013 and Zhang et al., 2015.

Figura 1. La cuenca Amazónica con los ríos Madeira y Solimões, sus patrones climáticos y corrientes oceánicas regionales superficiales. El punto indica la posición del testigo GeoB16224-1, las líneas discontinuas continentales corresponden al dipolo de anomalías de precipitación de América del Sur (SAPD en inglés), las líneas discontinuas sobre el mar a las posiciones de invierno (Dec) y verano (Jun) de la ITCZ y las flechas sólidas a las corrientes oceánicas regionales superficiales: NEC: Corriente del Norte, GC: Corriente de la Guayana, NBC: Corriente del Norte de Brasil, RNBC: Retroflexión de la Corriente del Norte de Brasil. Fuentes de información: Cheng et al., 2013 y Zhang et al., 2015.

finally, analysed in the mass spectrometer. (2) REEs column: the obtained matrix was dried out and dissolved in $2 \mathrm{~mL}$ of $\mathrm{HNO}_{3} 1 \mathrm{M}$, allowing just the REEs to be aggregated. (3) LN column: the REEs dissolution was dried out and once more dissolved in $0.2 \mathrm{~mL}$ of
$\mathrm{HCl} 0.26 \mathrm{M}$, allowing just the $\mathrm{Nd}$ to be collected and analysed in the mass spectrometer.

Both the chemical preparation of samples and the $\mathrm{Nd}$ - and Sr-isotopic data collection have been done at the Universidade de São Paulo (USP) in the laborato- 
I. Ruiz and L. Pena, 2018. Neodymium and Strontium isotopes as source indicators for... Boletín Geológico y Minero, 129 (4): $633-646$

ry of the Centro de Pesquisas Geocronológicas (CPGeo). The acquisition of the data was carried out using a Thermo-Neptune Plus high-performance multi-collector ICP-MS (Inductively Coupled PlasmaMass Spectrometry) for $\mathrm{Nd}$ and a Thermo-Tritonmulticollector TIMS (Thermal Ionization Mass Spectrometer) for Sr. Data processing and calculations of ${ }^{143} \mathrm{Nd} /{ }^{144} \mathrm{Nd}$ and ${ }^{87} \mathrm{Sr} /{ }^{86} \mathrm{Sr}$ ratios were conducted by the Instituto de Geociências (IGc-USP). A total of 15 samples was analysed, making 30 isotopic analysis. JNdi-1 analytical standard gave values of $0.512098 \pm 0.000006$ for ${ }^{143} \mathrm{Nd} /{ }^{144} \mathrm{Nd}(2 \sigma)$ and NBS-987 standard was $0.710264 \pm 0.000040(2 \sigma)$ for ${ }^{87} \mathrm{Sr} /{ }^{86} \mathrm{Sr}$. Neodymium ratio $\left({ }^{143} \mathrm{Nd} /{ }^{144} \mathrm{Nd}\right)$ will be expressed using the $\varepsilon_{\mathrm{Nd}}$ notation, where:

$$
\varepsilon_{N d}=\left(\frac{\left({ }^{143} N d / /^{144} N d\right) \text { sample }}{\left({ }^{143} N d / /^{144} N d\right) C H U R}-1\right) \times 10^{4}
$$

with ${ }^{143} \mathrm{Nd} /{ }^{144} \mathrm{Nd} \mathrm{CHUR}$ (Chondritic Uniform Reservoir) current value of 0.512638 (Jacobsen and Wasserburg, 1980).

\section{Results}

All isotope results are represented in Table 1 and plotted in Figures 2 and 4. For a better comparison of the Sr data, Nd from Zhang et al. (2015) has also been included. Radiogenic isotope geochemistry ${ }^{143} \mathrm{Nd} /{ }^{144} \mathrm{Nd}$ and ${ }^{87} \mathrm{Sr} /{ }^{86} \mathrm{Sr}$ ranges between 0.512011 to 0.512068 and 0.712422 to 0.715750 , respectively. $\varepsilon_{\mathrm{Nd}}$ values are negative (non-radiogenic) and notably uniform, exhibiting a change between -12.22 and -11.11 . Sr isotopes exhibit constant values, with an excursion of 0.00333 (from 0.712422 to 0.715750 ) found within the two first measurements at the age of 5.3 and 6 kry BP. Consequently, the signal for the period of the late Holocene appears to have a continuous trend towards heavier $\mathrm{Sr}$ ratios, and ultimately, the LGM shows very homogenous values in comparison to the time period before (from 24 to $30 \mathrm{kyr} B P$ ), where the ratio values are more scattered.

Goldstein et al. (1984) state that the homogeneity of $\mathrm{Nd}$ isotope compositions might be attributed to either a mixing of isotopically heterogeneous material by contemporary erosional cycles or to an overall sampling of material with similar $\mathrm{Nd}$ isotopic ratios. Available data support the latter explanation, as (a) $\mathrm{Nd}$ isotopic compositions in products of erosion appear to be largely dependent on the lithology and the diverse tectonic settings within the source region and (b) Sr isotope characterization is pretty constant;

\begin{tabular}{|c|c|c|c|c|}
\hline $\begin{array}{c}\text { Depth } \\
(\mathrm{cm})\end{array}$ & $\begin{array}{c}\text { Age } \\
(\mathrm{yr} \mathrm{BP})\end{array}$ & $\begin{array}{c}{ }^{143} \mathrm{Nd} /{ }^{144} \mathrm{Nd} \\
\left( \pm 2 \sigma \times 10^{-6}\right)\end{array}$ & $\varepsilon_{\mathrm{Nd}}$ & $\begin{array}{c}{ }^{87} \mathrm{Sr} /{ }^{86} \mathrm{Sr} \\
\left( \pm 2 \sigma \times 10^{-6}\right)\end{array}$ \\
\hline 10 & 5295 & $0.512042(8.6)$ & -11.62 & $0.712422(4.9)$ \\
\hline 40 & 6075 & $0.512065(10.8)$ & -11.18 & $0.715750(5.2)$ \\
\hline 70 & 9566.4 & $0.512052(8.1)$ & -11.44 & $0.715209(4.4)$ \\
\hline 100 & 14413 & $0.512034(7.5)$ & -11.78 & $0.713248(5.0)$ \\
\hline 130 & 15683 & $0.512039(10.5)$ & -11.68 & $0.713619(6.3)$ \\
\hline 160 & 16955 & $0.512011(7.5)$ & -12.22 & $0.714088(4.9)$ \\
\hline 190 & 18230 & $0.512042(6.4)$ & -11.63 & $0.713845(5.2)$ \\
\hline 220 & 19688 & $0.512050(6.6)$ & -11.47 & $0.713975(5.2)$ \\
\hline 250 & 21238 & $0.512062(7.5)$ & -11.23 & $0.713857(4.9)$ \\
\hline 280 & 22408 & $0.512052(8.2)$ & -11.44 & $0.714201(5.1)$ \\
\hline 310 & 23698 & $0.512042(9.5)$ & -11.62 & $0.714057(4.6)$ \\
\hline 340 & 25226 & $0.512044(7.9)$ & -11.59 & $0.712797(4.3)$ \\
\hline 370 & 26520 & $0.512068(7.1)$ & -11.11 & $0.714194(4.9)$ \\
\hline 400 & 27696 & $0.512062(8.3)$ & -11.23 & $0.713164(5.5)$ \\
\hline 430 & 29550 & $0.512034(9.4)$ & -11.78 & $0.714743(4.3)$ \\
\hline
\end{tabular}

Table 1. Nd and $\mathrm{Sr}$ isotopic data obtained results at USP, Brazil. $\varepsilon_{\mathrm{Nd}}$ describe the deviation of ${ }^{143} \mathrm{Nd} /{ }^{144} \mathrm{Nd}$ (in parts per $10^{4}$ ) from the CHUR reservoir.

Tabla 1. Datos isotópicos de $\mathrm{Nd}$ y Sr obtenidos en USP, Brasil. $\varepsilon_{\mathrm{Nd}}$ describe la desviación de ${ }^{143} \mathrm{Nd} /{ }^{144} \mathrm{Nd}$ (en partes por $10^{4}$ ) del reservorio de CHUR.

both factors leading to the same fractionation process.

The provenance of the reported results can be achieved by using $\mathrm{Sr}$ values to trace the pathway of the sediments and $\mathrm{Nd}$ to indicate the composition of the source rocks.

\section{Discussion}

The most important sediment source reaching the continental slope of NE South America is the terrigenous material via fluvial input, carried by the Amazon River and continuously deposited in the deep-sea Amazon fan. Aeolian deposition is considered to be insignificant, since the main winds -the NE trade winds- blow from the Atlantic Ocean into the continent supplying moisture to the mainland (Behling et al., 2000). This seems to hold true even for the Heinrich Stadial 1 (HS-1), when the Sahara-Sahel desert experienced and expansion and thus, enhanced its supply of African dust (Collins et al., 2013). However, $\varepsilon_{\mathrm{Nd}}$ values of African dust are different from the Amazon-sourced ones (see Zhang et al., 2015). Therefore, the discussion of our results will focus on the terrigenous material transported by the Amazon River. 
Because $\mathrm{Sr}$ isotopes were analysed for the bulk sediment without prior differentiation of the detritus fraction, two potential influences on the Sr signal of this dataset might be the effect of marine carbonates and grain size fractionation. On the one hand, the observation that throughout our $\mathrm{Sr}$ record, isotope ratios are far from the present day seawater values (0.7091) is a strong indication that the in situ carbonate contribution has been minimal for the studied period (Bayon et al., 2002). Hence, the high variability of the $\mathrm{Sr}$ ratio advocates a minimum contribution of marine carbonates into the analysed isotopic composition (see Goldstein and Hemming, 2003). On the other hand, the potential influence of a grain size frac- tionation process has been reported to be high for the river sediments of the Amazon Basin as a function of the bedrock composition, weathering intensity -as a proxy for rainfall- and hydrodynamic processes during transport (Bouchez et al., 2011). As stated earlier, all the samples of this dataset have been obtained at the same water depth $(-2510 \mathrm{~m})$ and share a common source area (and thus, have also been transported by the same river). In this manner, possible fractionation processes due to differences in the bedrock composition of the samples or due to hydrodynamic processes during transportation have been ruled out.

In the light of these clarifications, and in order to analyse the terrigenous material transported by the

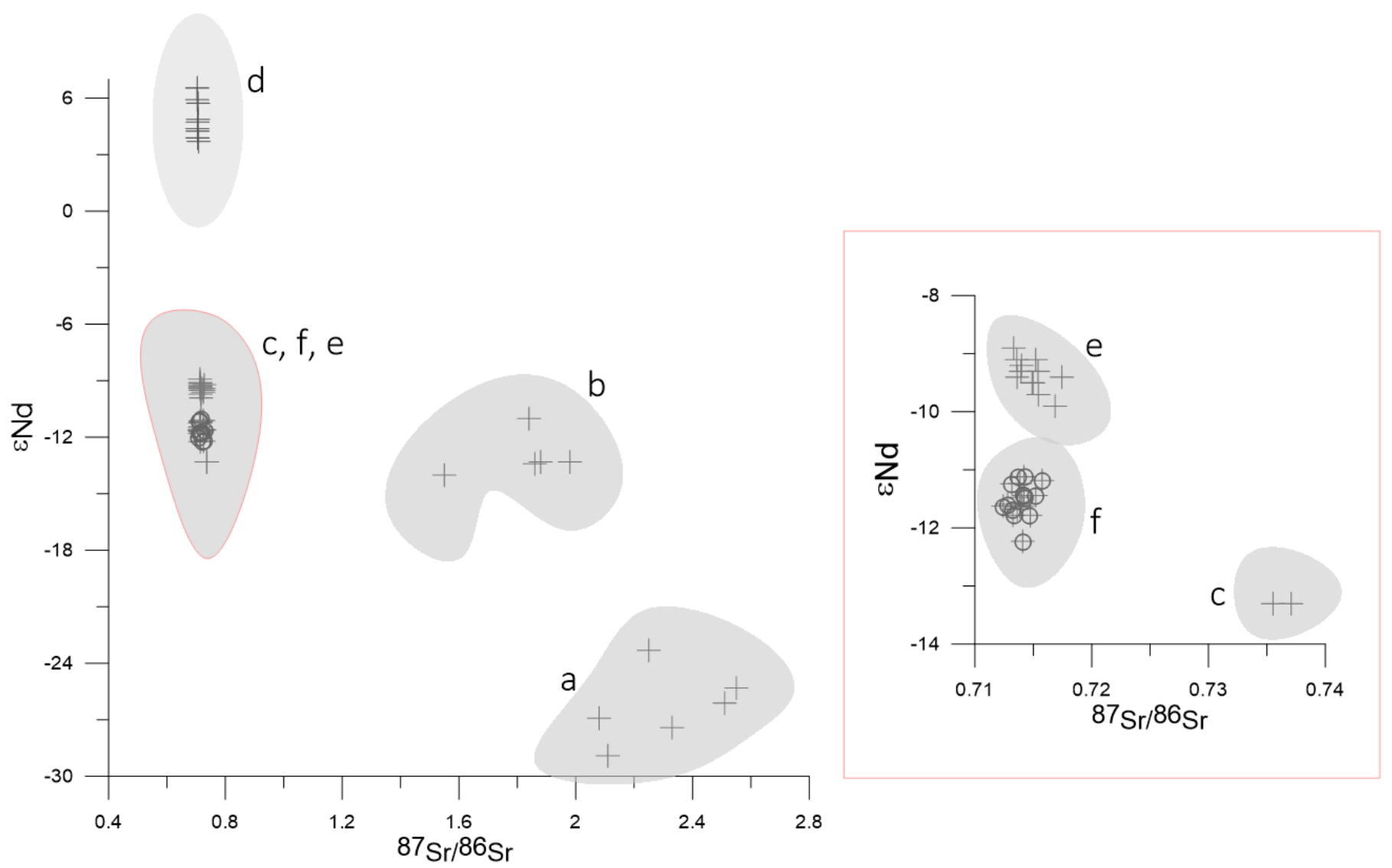

Figure 2. Isotopic data obtained within this study (f, Nd results published by Zhang et al., 2015) plotted in the $\varepsilon_{\mathrm{Nd}} \mathrm{versus}{ }^{87} \mathrm{Sr} /{ }^{86} \mathrm{Sr}$ diagram. Previously published data for northern South American cratonic, Andean and Amazon basin cover rocks is shown here. (a) Guiana and Central Brazil shields (van Schmus et al., 1995); (b) Reworked Guiana and central Brazil shields (van Schmus et al., 2011); (c) Andean highlands (Parra and Pujos, 1998); (d) contaminated Andean high-land (Rogers and Hawkesworth, 1989); (e) Amazon basin cover rocks (Viers et al., 2008). A close-up of the (c), (f) and (e) fields is framed and placed to the right of the figure.

Figura 2. Los datos isotópicos obtenidos en este estudio (f, datos de Nd publicados por Zhang et al., 2015) se encuentran representados en el diagrama $\varepsilon_{N d}$ versus ${ }^{87} \mathrm{Sr}{ }^{\beta 6} \mathrm{Sr}$ junto con datos publicados anteriormente para rocas cratónicas, Andinas y de la cobertura rocosa de la cuenca del Amazonas. (a) Escudo Guayanés y rocas de Brasil central (van Schmus et al., 1995); (b) Rocas del Escudo retrabajadas (van Schmus et al., 2011); (c) Rocas Andinas (Parra and Pujos, 1998); (d) Rocas Andinas contaminadas (Rogers and Hawkesworth, 1989); (e) Cobertura rocosa de la cuenca Amazónica (Viers et al., 2008). La amplificación de los campos (c), (f) y (e) se encuentra enmarcada y colocada a la derecha de la figura. 
Amazon River, the first step is to characterize the source area of the sediment fraction by comparing the presented measurements with data from the literature (Fig. 2). Then, the paleoclimatic implications of these results will be examined.

\section{Characterization of the different reservoirs}

Previously published data show different geochemical characteristics for each main terrestrial source area within northern South America, having welldefined Sr-Nd isotopic signatures (e.g. Goldstein et al., 1984; Rogers and Hawkesworth, 1989; Basu et al., 1990; van Schmus et al., 1995, 2011; Parra and Pujos, 1998; Viers et al., 2008). In order to contextualize our results we have included and represented all these datasets together (Fig. 2).

The isotopic pattern of the studied area (the Amazon River basin) incorporates signatures from three main source areas, which correspond to the three main geotectonic provinces: (a) the Amazon basin cover rocks, (b) the Andes mountain range (ridge and Sub Andean fold-thrust) and (c) the Guiana and Central Brazil shields (Fig. 3).
Amazon basin cover rocks (Fig. 3a): the drainage basin of the Amazon River covers approximately $6.2 \times 10^{6} \mathrm{~km}^{2}$. The mouth of the river lies on the eastern margin of the continent, with headwaters as far west as the Andean mountain belt (McDaniel et al., 1997). The basin is bounded on the west by the sub-Andean fold-thrust belt and on the east by the Guianan and Brazilian shields. Around $30 \%$ of the Amazon River flows across floodplains, which are dominated by Andean alluvium and deposited annually with seasonal floods (Figueiredo et al., 2009). Modern Amazon River suspended sediments (Fig. 2e) have been investigated by many authors. Values for $\varepsilon_{\mathrm{Nd}}$ are regularly slightly negative, from ca. -10 to -8.8 and therefore clearly indicating the erosion of Quaternary and Tertiary sediments from the basin's cover (Viers et al., 2008). The ${ }^{87} \mathrm{Sr} /{ }^{86} \mathrm{Sr}$ ratio for this dataset exhibits low values in comparison to the ones of Viers et al. (2008), suggesting that the provenance of the eroded sediments is closer to the Andes mountain ridge.

The Andes mountain range (Fig. 3b): the Andes mountain range runs the entire length of the western margin of South America. Therefore, the influence of climate, erosional processes, and tectonics on the orogenic morphology depends on the zonal climate

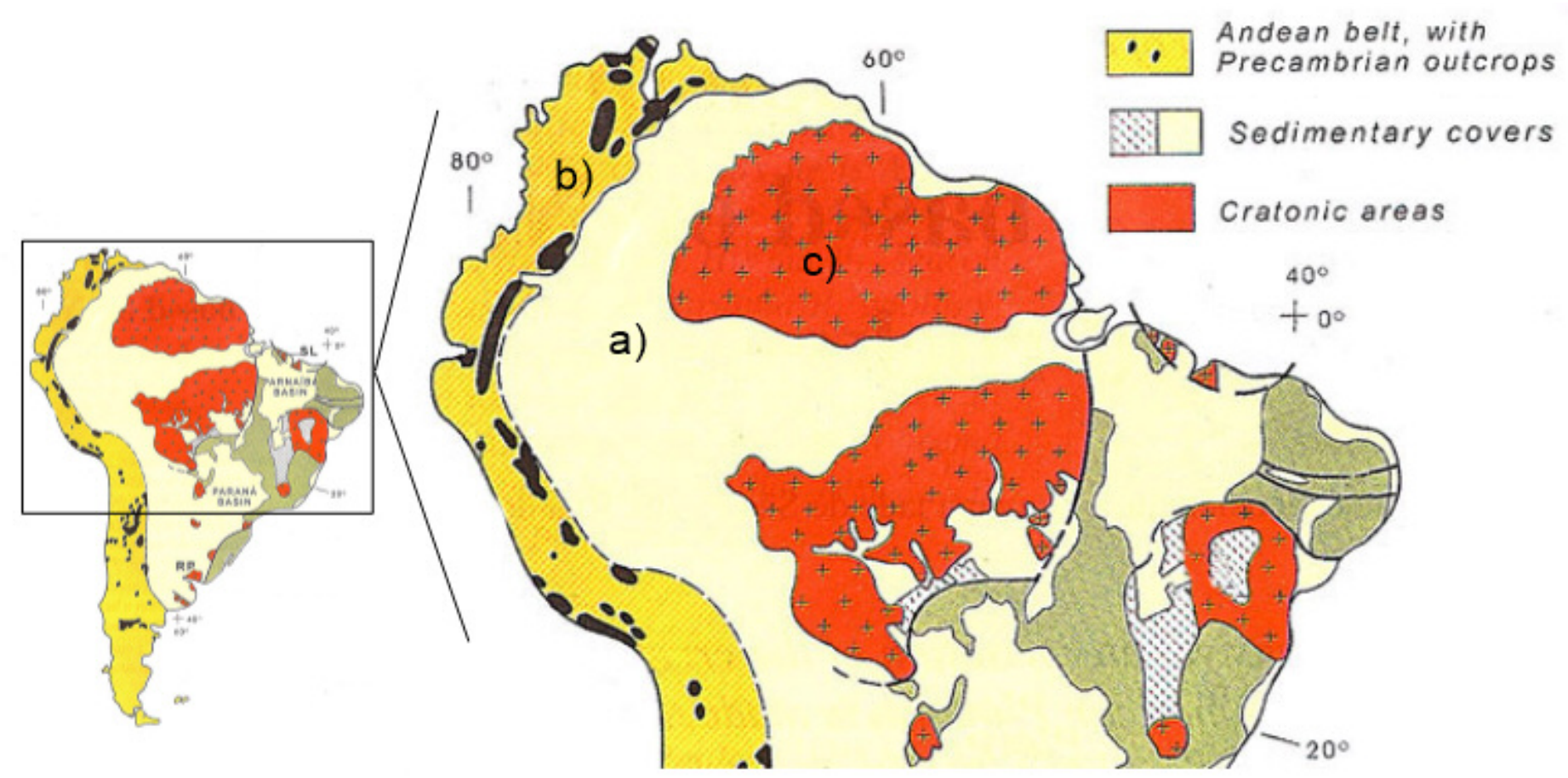

Figure 3. Simplified scheme of the South American geological map. (a) Amazon basin cover rocks, (b) Andes mountain range, and (c) Guiana and Central Brazil shields. Modified from geo.arizona.edu.

Figura 3. Esquema simplificado del mapa geológico sudamericano. (a) Cobertura rocosa de la cuenca Amazónica, (b) Rocas Andinas, y (c) Escudo Guayanés y rocas de Brasil central. Modificado de geo.arizona.edu. 
patterns. This mountain range consists of Paleozoic to Holocene volcanic and plutonic rocks representing accreted island arc, back arc and continental arc suites with varying amounts of crustal incorporation, metamorphosed basement and thrust sedimentary rocks (McDaniel et al., 1997). The Andean arc has been associated with the western Brazilian shield throughout its history. Consequently, negative $\varepsilon_{\mathrm{Nd}}$ values from Andean and sub-Andean rocks exist because of the incorporation of old crust into mantle melts. Thus, sediments being actively eroded from the Andean highlands show a more negative $\varepsilon_{N d}$ than the igneous rocks from the Mesozoic (Fig. 2c). ${ }^{87} \mathrm{Sr} /{ }^{86} \mathrm{Sr}$ values of our dataset exhibit a lower Sr ratio, evidencing a distinct provenance of the sediments. Rogers and Hawkesworth (1989) reported highly fractionated REE patterns in igneous rocks from the Central Andean ridge, at $22^{\circ} \mathrm{S}$ latitude. Strongly radiogenic $\varepsilon_{\mathrm{Nd}}$ values are interpreted to indicate a change in the character of the magmatism, suggesting a contamination of mantle-derived magma by crustal sources (Fig. 2d).

Guiana and Central Brazil shields (Fig. 3c): the Amazonian Craton is a large area of exposed Precambrian crystalline igneous and high-grade metamorphic rocks surrounded by the Neoproterozoic Sergipano orogenic belt. It is divided into six major geochronological provinces, with formation ages ranging from $>2.3 \mathrm{Gyr}$ to $1.0 \mathrm{Gyr}$ (Tassinari and Macambria, 1999). According to the authors, each province contains orogenic igneous rocks, indicating a reworking of the older continental crust, and sedimentary covers of widely different ages (Fig. 2b). Basu et al. (1990) reported that "rocks evolve over time toward more negative $\varepsilon_{N d}$ values at the rate of approximately $1 \varepsilon_{N d}$ unit per 80-100 Myr." Accordingly, sediments directly eroded from cratonic areas will have the lowest $\varepsilon_{\mathrm{Nd}}$ values (Fig. 2a) in comparison to reworked material with lower $\varepsilon_{\mathrm{Nd}}$ values of around -29 to -23 but yet, high ${ }^{87} \mathrm{Sr} /{ }^{86} \mathrm{Sr}$ ratios (Fig. 2b).

All samples analysed within this study and Zhang et al. (2015) (Fig. 2f) have very similar Sr ratios around 0.71385 and negative $\varepsilon_{\mathrm{Nd}}$ values around $-11.67 \pm 0.55$. On the basis of the isotopic data and in accordance with the previously reported studies, our $\mathrm{Sr}$ and $\mathrm{Nd}$ signatures suggest that the sediments deposited off French Guiana during the last ca. 30 kyr BP have been derived from the westernmost Amazon basin, which is partially over the subsiding western Amazonian foreland basin. Therefore, we are able to confirm that the source area is Quaternary and Tertiary sediments that contain a significant proportion of continental crust of older $\varepsilon_{\mathrm{Nd}}$ signature (Parra and Pujos, 1998; Viers et al., 2008). This occurs in the reworked sediments from the western Amazonian basin which have a component of Andean Nd.

\section{Characterization of the sub-region}

Erosion and transportation of terrestrial material from the westernmost Amazon basin might occur through two main rivers, the Solimões and the Madeira rivers (Fig. 1). In order to disentangle from which of the two basins our samples are most likely to be originally eroded, we will compare the isotopic signatures of our data with previously reported studies (i.e. Viers et al., 2008; Bouchez et al., 2011; Horbe et al., 2014) (see Fig. 4). We are able to initially differentiate between the two, although it is necessary to bear in mind that this is a modest dataset with Sr limitations.

$\varepsilon_{\mathrm{Nd}}$ values from Zhang et al. (2015) and ${ }^{87} \mathrm{Sr} /{ }^{86} \mathrm{Sr}$ isotopic data clearly fall within the isotopic values of the Solimões basin (Viers et al., 2008; Bouchez et al., 2011; Horbe et al., 2014), with a ${ }^{87} \mathrm{Sr} /{ }^{86} \mathrm{Sr}$ range of values of $0.710-0.725$ and a $\varepsilon_{N d}$ main range value of $-8-12.5$. Thus, we suggest that the samples analysed here come from this sub-region.

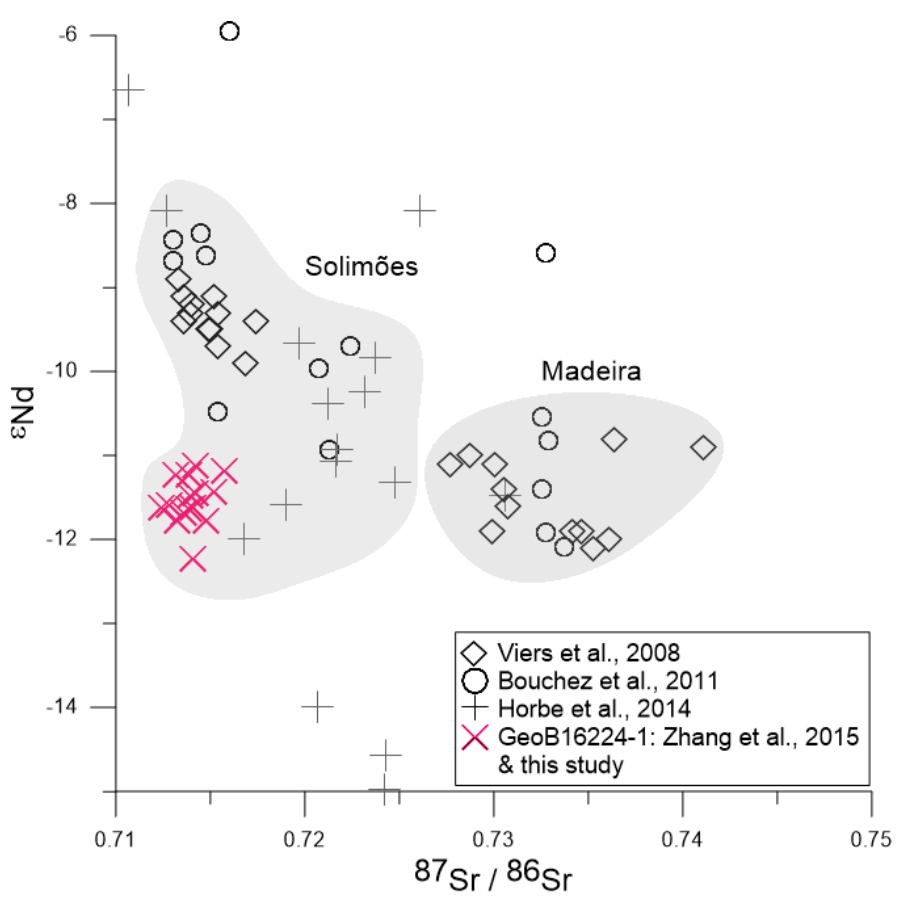

Figure 4. Isotopic data obtained within this study ( $\mathrm{Nd}$ results published by Zhang et al., 2015) plotted in the $\varepsilon_{\mathrm{Nd}}$ versus ${ }^{87} \mathrm{Sr} /{ }^{86} \mathrm{Sr}$ diagram. Previously published data from Viers et al. (2008), Bouchez et al. (2011) and Horbe et al. (2014) correspond to Quaternary terraces of the Amazonian foreland basin.

Figura 4. Los datos isotópicos obtenidos en este estudio (datos de Nd publicados por Zhang et al., 2015) se encuentran representados en el diagrama $\varepsilon_{N d}$ versus ${ }^{87} \mathrm{Sr}{ }^{\beta 6} \mathrm{Sr}$ junto con datos publicados anteriormente por Viers et al. (2008), Bouchez et al. (2011) y Horbe et al. (2014), que corresponen a terrazas Cuaternarias de la cuenca de antepaís Amazónica. 


\section{Paleoclimatic implications}

As this dataset is relative to precessional-scale insolation changes, we will be only discuss millennial events. More specifically and related to the landocean temperature gradient (a) the Holocene in comparison to the Last Glacial Maximum (LGM) will be addressed, together with an insight into the (b) Heinrich events 1, 2 and 3 (HS-1, HS-2, and HS-3). Likewise, and due to the limited number of data points, this dataset does not allow for the analysis of shorter timescale interpretations. However, together with previous studies conducted in the area, paleoclimatic implications of the reported results can be analysed and contextualized.

(a) Here we report constant ${ }^{87} \mathrm{Sr} /{ }^{86} \mathrm{Sr}$ high values for the LGM and late-Holocene (one data point), with a strong drop of the Sr ratio coinciding with the starting of the mid-Holocene low austral summer insolation phase (Fig. 5c); these values suggest that the

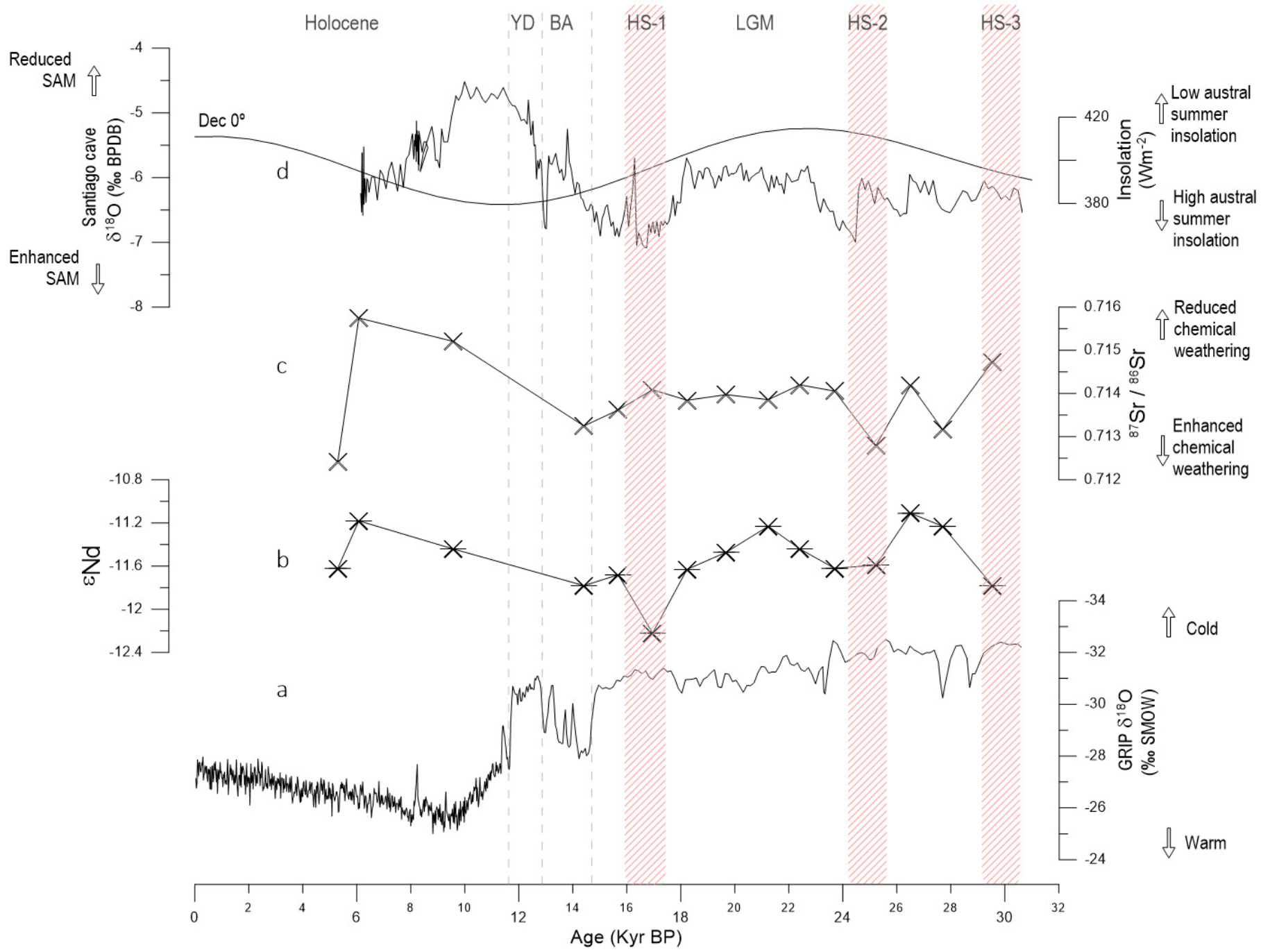

Figure 5. Comparison amongst records regarding age in thousand years: (a) $\delta^{18} \mathrm{O}$ ice record on the GICC05 (Vinther et al., 2008$)$, (b) $\varepsilon_{\mathrm{Nd}}$ values for GeoB 16224-1 (Zhang et al., 2015), (c) Sr ratio isotopic values for GeoB 16224-1 and (d) Santiago's cave $\delta^{18} \mathrm{O}$ speleothem record (Mosblech et al., 2012) together with the austral summer (Dec) insolation at $0^{\circ}$ latitude (Berger and Loutre, 1991). Dashed vertical bars indicate Heinrich Stadials. YD: Younger Dryas, BA: Bølling-Allerød, HS-: Heinrich Stadials, LGM: Last Glacial Maximum.

Figura 5. Comparación entre registros con respecto al tiempo en miles de años: (a) registro de $\delta^{18} \mathrm{O}$ en hielo (Vinther et al., 2008), (b) valores de $\varepsilon_{N d}$ en GeoB 16224-1 (Zhang et al., 2015), (c) ratio de valores de Sr en GeoB 16224-1 y (d) valores de $\delta^{18} O$ de la cueva de Santiago (Mosblech et al., 2012) junto con la insolación austral de verano (Dec) a $0^{\circ}$ de latitud (Berger and Loutre, 1991). Las barras verticales discontinuas indican Heinrich Stadials. YD: Younger Dryas, BA: Bølling-Allerød, HS-: Heinrich Stadials,LGM: Last Glacial Maximum. 
Holocene presented a lower chemical weathering rate than the LGM. In consonance with our results, western Amazonian speleothem records from Mosblech et al. (2012) and Cheng et al. (2013), and glacial lake sediment samples recovered in the Andes from Baker et al. (2001a, b) suggest that the early Holocene (i.e. 10-5 kyr BP) was drier than the LGM.

$\delta^{18} \mathrm{O}$ speleothem variability in the westernmost Amazon basin caves and the subsiding western Amazonian foreland sites is interpreted to reflect changes in the source and amount of precipitation. That is, the amount effect and Rayleigh-type fractionation process (Dansgaard, 1964), as the temperature effect in this climate zone is considered insignificant (e.g. Kanner et al., 2012). Thus, the amount of rainfall in this area is largely related to the South American monsoon (SAM) exhibiting $\delta^{18} \mathrm{O}$ records depleted values during wet seasons (Baker and Fritz, 2015). In this way, the rainfall pattern is suggested to be coupled to precessional variations, with increased rainfall during the high austral summer insolation period of the LGM and mid-late Holocene, resulting from a more intense SAM where tropical Atlantic moisture is recycled over the Amazon basin (Fig. 5d).

Comparisons between east and west South American speleothems suggest an anti-phase in precipitation for the past $25 \mathrm{kyr}$. This anti-phase is known as the American Precipitation Dipole (SAPD, see Fig. 1). Thus, this regime of precipitations found in western Amazon is reported to be opposite for eastern South America and NE Brazil, resulting in enhanced precipitations for the LGM and scare annual precipitations for the late-Holocene for the western Amazon (Cruz et al., 2009; Prado et al., 2013a; Wang et al., 2007).

(b) Sr values for the HS-1 and HS-2 events (Fig. 5c) are around 0.7140 and 0.7127 , suggesting a chemical weathering rate similar to the LGM for the HS-1, and the highest chemical weathering rate of the entire record for the HS-2. Together with the Sr results, the Nd signal from Zhang et al. (2015) exhibits lower $\varepsilon_{\mathrm{Nd}}$ values, implying an increase in suspended sediments of Andean tributaries for both events (Fig. 5b). In line with our results, marine sediments from Jaeschke et al. (2007) and Zhang et al. (2015) and speleothem records from Wang et al. (2004), Kanner et al. (2012) and Mosblech et al. (2012) exhibit positive precipitation anomalies during Heinrich Stadials for almost the whole Amazon basin (Fig. 5d).

As reported by these authors, during HS abrupt episodes, the latitudinal temperature gradient of the Atlantic is enhanced, resulting from a greater meltwater input into the high latitudes of the North Atlantic that reduces the Atlantic Meridional Overturning Circulation (AMOC). The reduction of the
AMOC results in a higher land-ocean temperature gradient, which triggers the strengthening of the NE trade winds, displacing the ITCZ towards the south. On-land consequences of this are increased precipitation, physical erosion, and fluvial transportation. Despite the limited control of the ITCZ over the water cycle of the whole Amazon basin (Grimm et al., 2015) the strengthening of the NE trade winds also provides enhanced moisture to the SAM, intensifying the precipitation levels along the eastern scarp of the Andes (Mechoso et al., 2015).

In contrast to the HS-1 and HS-2, at the time of low austral autumn, HS-3 exhibits dry conditions. This finding is in line with Mosblech et al. (2012) and Cruz et al. (2005), who report a missing abrupt and wet signals for the HS-3 in their respective records. Furthermore and together with HS-6, HS-3 has been considered an anomalous Heinrich event, as both HSs show a modest increase in the Ice Rafter Detritus (IRD) flux in comparison to the HS-1, HS-2, HS-4 and HS-5 (see Hemming, 2004); thus, presenting a plausible explanation for our result.

\section{Conclusions}

It has been possible to constrain the provenance of terrigenous sediments deposited off NE South America with the combination of $\mathrm{Nd}$ (Zhang et al., 2015) and $\mathrm{Sr}$ isotope analyses, making them suitable as source indicators. All reported results show $0.71385 \pm 0.00166 \mathrm{Sr}$ ratios and $-11.67 \pm 0.55 \varepsilon_{\mathrm{Nd}}$ values, therefore suggesting a unique source for the analysed samples. The most likely source area for this set of samples is the Solimões River, which has its drainage basin in the westernmost Amazon basin, partially over the subsiding western Amazonian foreland basin. Previous climatic studies conducted in the area enable the contextualization of our results, which exhibit millennial-scale variations. These variations are congruent with western Amazon speleothems profiles, NE Brazilian sediment cores, and Peruvian Andes lake records, further supporting the inferred origin of these analysed terrigenous sediments. Our results within this modest project have enabled the investigation of the inland paleoclimatic reconstruction of the western Amazon basin and prove the suitability of this approach as a paleoclimatic proxy.

\section{Acknowledgements}

We are grateful for technical support from the Instituto de Geociências - University of São Paulo for 
I. Ruiz and L. Pena, 2018. Neodymium and Strontium isotopes as source indicators for... Boletín Geológico y Minero, 129 (4): $633-646$

the $\mathrm{Nd}$ and $\mathrm{Sr}$ isotopes values training and acquisition, specially to Dr. C.M. Chiessi. To the Core Repository at Marum - University of Bremen, for supplying the sediment samples, and to Dr. S. Mulitza for his suppervision. We would also like to thank the work and the constructive commentaries from the two reviewers, who greatly helped the improvement of this paper. We are especially grateful to Aline Govin for her thoughtful revision. Finally, thanks to Josué M. Polanco, guest co-editor of this special number for his guidance and support. This study was integrated within the "Response of Amazon sedimentation to deforestation, land use and climate" (AMADEUS) project.

\section{References}

Allégre C.J., Dupré B., Négrel P. and Gaillardet J. 1996. Sr$\mathrm{Nd}-\mathrm{Pb}$ isotope systematics in Amazon and Congo River systems: Constraints about erosion processes. Chemical Geology, 131, 93-112.

Allison, M.A., Lee, M.T., Ogston, A.S. and Aller, R.C., 2000. Origin of Amazon mud banks along the northeast coast of South America. Marine Geology, 163, 241-256.

Baker, P.A., Rigsby, C.A., Seltzer, G.O., Fritz, S.C., Lowenstein, T.K., Bacher, N.P. and Veliz, C. 2001a. Tropical climate changes at millennial and orbital timescales in the Bolivian Altiplano. Nature, 409, 698-701.

Baker, P.A., Seltzer, G.O., Fritz, S.C., Dunbar, R.B., Grove, M.J., Tapia, P.M., Cross, S.L., Rowe, H.D. and Broda, J.P., $2001 \mathrm{~b}$. The history of South American tropical precipitation for the past 25,000 years. Science, 291, 640-643.

Baker, P.A. and Fritz, S.C. 2015. Nature and causes of Quaternary climate variation of tropical South America. Quaternary Science Reviews, 124, 31-47.

Basu, A.R., Sharma M. and DeCelles P.G. 1990. Nd, Sr-isotopic provenance and trace element geochemistry of Amazonian foreland basin fluvial sands, Bolivia and Peru: implications for ensialic Andean orogeny. Earth and Planetary Science Letters, 10, 01-17.

Bayon, G., German, C.R., Boella, R.M., Milton, J.A., Taylor, R.N. and Nesbitt, R.W. 2002. An improved method for extracting marine sediment fractions and its application to $\mathrm{Sr}$ and $\mathrm{Nd}$ isotopic analysis. Chemical Geology, 187, 179-199.

Behling, H., Arz, H.W., Pätzold, J and Wefer, G. 2000. Late Quaternary vegetational and climate dynamics in northeastern Brazil, inferences from marine core GeoB 31041, Quaternary Science Reviews, 19, 981- 994.

Berger, A. and Loutre, M.F. 1991. Insolation values for the climate of the last 10 million of years. Quaternary Sciences Review, 10 (4), 297-317.

Bouchez, J., Gaillardet, J., France-Lanord, C., Maurice,L., and Dutra-Maia, P. 2011. Grain size control of river suspended sediment geochemistry: Clues from Amazon River depth profiles, Geochemistry Geophysics Geosystems, 12, Q03008. doi: 10.1029/2010gc003380, 2011.
Bourlès, B., Gouriou, Y. and Chuchla R. 1999. On the circulation in the upper layer of the western equatorial Atlantic. Journal of Geophysical Research, 104 (C9), 21151-21170. doi: 10.1029/1999JC900058.

Cheng, H., Sinha, A., Cruz, F.W., Wang, X., Edwards, R.L., d'Horta, F.M., Ribas, C.C., Vuille, M., Stott, L. D. and Auler, A.S. 2013. Climate change patterns in Amazonia and biodiversity. Nature Communications, 4, 1411. doi: 10.1038/ncomms2415.

Collins, J.A., Govin, A., Mulitza, S., Heslop, D., Zabel, M., Hartmann, J., Röhl, U. and Wefer, G. 2013. Abrupt shifts of the Sahara-Sahel boundary during Heinrich stadials. Climate of the Past, 9, 1181-1191. doi: 10.5194/cp-9-11812013, 2013.

Cruz, F.W., Burns, S.J., Karmann, I., Sharp, W.D., Vuille, M., Cardoso, A.O., Ferrari, J.A., Dias, P.L.S. and Viana, O. 2005. Insolation-driven changes in atmospheric circulation over the past 116,000 years in subtropical Brazil. Nature, 434, 63-66.

Cruz, F.W., Vuille, M., Burns, S.J., Wang, X., Cheng, H.,Werner, M., Lawrence Edwards, R., Karmann, I., Auler, A.S., and Nguyen, H. 2009. Orbitally driven east-west antiphasing of South American precipitation. Nature Geosciences, 2, 210-214. doi: 10.1038/ngeo444, 2009.

Dansgaard, W. 1964. Stable isotopes in precipitation. Tellus. doi: 10.1111/j.2153-3490.1964.tb00181.x

DePaolo, D.J. and Wasserburg, G.J. 1976.Nd isotopic variations and petrogenetic models. Geophysical research letters, 3 (5), 249-252.

Figueiredo, J., Hoorn, C., van der Ven, P. and Soares, E. 2009. Late Miocene onset of the Amazon River and the Amazon deep-sea fan: Evidence from the Foz do Amazonas Basin. Geology, 37, 619-622.

Gierlowski-Kordesch, E.H., Jacobson, A.D., Blum, J.D. and Valero Garces, B.L. 2008. Watershed reconstruction of a Paleocene-Eocene lake basin using $\mathrm{Sr}$ isotopes incarbonate rocks. Geological Society of America Bulletin, 120, 85-95.

Goldstein, S.L., O’Nions, R.K. and Hamilton, P.J. 1984. A Sm$\mathrm{Nd}$ isotopic study of atmospheric dusts and particulates from major river systems. Earth and Planetary Science Letters, 70, 221-236.

Goldstein, S.L. and Hemming, S.R. 2003. 6.17 - Long-lived Isotopic Tracers in Oceanography, Paleoceanography, and Ice-sheet Dynamics. Treatise on Geochemistry, 6, 453-489.

Grimm, A.M., Vera, C.S., Mechoso, C.R., 2005. 15. The South American monsoon system, in: Chang, C.P., Wang, B., Lau, N.-C.G. (Eds.) The global monsoon system: research and forecast. World Meteorological Organization, Geneva, Switzerland.

Grodsky, S.A. and Carton, J.A. 2002. Surface drifter pathways originating in the equatorial Atlantic cold tongue. Geophysical Research Letters, 29 (23), 2147. doi: 10.1029/2002GL015788.

Hemming, S.R. 2004. Heinrich events: Massive late Pleistocene detritus layers of the North Atlantic and their global climate imprint. Reviews of Geophysics, 42, RG1005. 
Horbe, A.M.C., Trindade, I.R., Dantas, E.L., Santos, R.V. and Roddaz, M., 2014. Provenance of quaternary and modern alluvial deposits of the Amazonian floodplain (Brazil) inferred from major and trace elements and $\mathrm{Pb}-\mathrm{Nd}-\mathrm{Sr}$ isotopes. Palaeogeography, Palaeoclimatology, Palaeoecology, 411, 144-154.

Jacobsen, S.B. and Wasserburg, G.J. 1980. Sm-Nd isotopic evolution of chondrites. Earth and Planetary Science Letters, 50 (1), 139-155.

Jaeschke, A., Rühlemann, C., Arz, H., Heil, G., and Lohmann, G. 2007. Coupling of millennial-scale changes in sea surface temperature and precipitation off northeastern Brazil with high-latitude climate shifts during the last glacial period. Paleoceanography, 22 (4). doi: 10.1029/2006pa001391, 2007.

Kanner, L.C., Burns, S.J., Cheng, H., and Edwards, R.L. 2012. High-Latitude Forcing of the South American Summer Monsoon During the Last Glacial. Science, 335, 570-573.doi: 10.1126/science.1213397.

Lentz, S.J. 1995. Seasonal variations in the horizontal structure of the Amazon Plume inferred from historical hydrographic data. Journal of Geophysical Research: Oceans, 100, 2391-2400. doi: 10.1029/94jc01847.

McDaniel, D.K., McLennan, S.M. and Hanson, G.N. 1997. Provenance of Amazon fan muds: constraints from $\mathrm{Nd}$ and $\mathrm{Pb}$ isotopes. Proceedings of the Ocean Drilling Program, Scientific Results, 155, 169-176.

McLennan, S.M. Taylor, S.R. and McGregor V.R. 1984. Geochemistry of Archean metasedimentary rocks from West Greenland. Geochimica et Cosmochimica Acta, 48, 1-13.

Mechoso, C.R., Robertson, A.W., Ropelewski, C.F. and Grimm, A.M. 2015. 13. The American monsoon systems: an introduction, in: Chang, C.P., Wang, B., Lau, N.-C.G. (Eds.), The global monsoon system: research and forecast. World Meteorological Organization, Geneva, Switzerland.

Mearns, E.W. 1988. A samarium-neodimium isotopic survey of modem sediments from northern Britain. Chern. Gent., 73, 1- 13.

Mosblech, N.A.S., Bush, M.B., Gosling, W.D., Hodell, D.,Thomas, L., van Calsteren, P., Correa-Metrio, A., Valencia, B.G., Curtis, J. and vanWoesik, R. 2012. North Atlantic forcing of Amazonian precipitation during the last ice age. Natural Geosciences, 5 (11), 817-820. doi: 10.1038/ngeo1588.

Mulitza, S., Chiessi, C.M., Cruz, A.P.S., Frederichs, T.W., Gomes, J.G., Gurgel, M.H.C.,Haberkern, J., Huang, E., Jovane, L., Kuhnert, H., Pittauerová, D., Reiners, S-J., Roud, S.C., Schefuß, E., Schewe, F., Schwenk, T.A., Sicoli Seoane, J.C., Sousa, S.H.M.,Wangner, D.J. and Wiers, S. 2013. Response of Amazon sedimentation todeforestation, land use and climate variability. Cruise No.MSM20/3 - February 19- March 11, 2012 - Recife (Brazil) - Bridgetown (Barbados). MARIA S. MERIANBerichte, MSM20/3, 86 pp., DFGSenatskommission für Ozeanographie, doi: 10.2312/cr_msm20_3.

North Greenland Ice Core Project members. 2004. High-resolution record of Northern Hemisphere climate extend- ing into the last interglacial period. Nature, 431 (7005), 147-151.

Parra, M. and Pujos, M. 1998. Origin of late Holocene finegrained sediments on the French Guiana shelf. Continental Shelf Research, 18, 1613-1629.

Peterson, R.G. and Stramma, L. 1991. Upper-level circulation in the South Atlantic Ocean. Progress in Oceanography 26, 1-73.

Prado, L.F., Wainer, I., and Chiessi, C.M. 2013a. MidHolocene PMIP3/CMIP5 model results: Intercomparison for the South American Monsoon System. Holocene, 23, 1915-1920. doi: 10.1177/0959683613505336.

Reimer, P.J., Bard, E., Bayliss, A., Beck, J.W., Blackwell, P.G., Bronk Ramsey, C., Buck, C.E., Cheng, H., Lawrence Edwards, R., Friedrich, M., Grootes, P.M., Guilderson, T.P., Haflidason, H., Hajdas, I., Hatté, C., Heaton, T.J., Hoffman, D.L., Hogg, A.G.,Reimer, R.W., Richards, D.A., Marian Scott, E., Southon, J.R., Staff, R.A., Turney, C.S.M. and van der Plicht, J. 2013. Initial 13 and marine 13 radiocarbon age calibrationcurves $0-50,000$ years CAL BP. Radiocarbon, 55 (4), 1869-1887.

Richardson, P.L. and Reverdin, G. 1987. Seasonal cycle of velocity in the Atlantic North Equatorial Countercurrent as measured by surface drifters, current meters, and ship drifts. Journal of Geophysical Research, 92: doi: 10.1029/JC092iC04p03691.

Rogers, G. and Hawkesworth, C.J. 1989. A geochemical traverse across the North ChileanAndes: evidence for crust generation from the mantle wedge. Earth and Planetary Science Letters, 91, 271-285.

Shao, L., Yuan, S., Li, C., Kang, C., Zhu, W., Liu, Y. and Wang, J. 2015. Changing provenance of late Cenozoic sediments in the Jianghan Basin. Geoscience Frontiers 6 (4), 605-615.

Stuiver, M. and Reimer, P.J. 1993. Extended ${ }^{14} \mathrm{C}$ data base and revised CALIB $3.014 \mathrm{C}$ age calibration program. Radiocarbon 35, 215-230.

Tassinari, C.C.G.and Macambira, M.J.B. Geochronological provinces of the Amazonian Craton. Episodes, 22 (3), 174-182.

van Schmus, W.R., de Brito Neves, B.B., Hackspacher, P. and Babinski. M. 1995. U/Pb and $\mathrm{Sm} / \mathrm{Nd}$ geochronologic studies of the eastern Borborema Province, Northeastern Brazil: initial conclusions. Journal of South American Earth Sciences, 8, 267-288.

van Schmus, W.R., Kozuch, M. and de Brito Neves, B.B. 2011. Precambrian history of the Zona Transversal of the Borborema Province, NE Brazil: Insights from Sm-Nd and U-Pb geochronology. Journal of South American Earth Sciences, 31, 227-252.

Viers, J., Roddaz, M., Filizola, N., Guyot, J.-L., Sondag, F., Brunet, P., Zouiten, C., Boucayrand, C., Martin, F. and Bonaventura, G.R. 2008. Seasonal and provenance controls on $\mathrm{Nd}-\mathrm{Sr}$ isotopic compositions of Amazon rivers suspended sediments and implications for $\mathrm{Nd}$ and $\mathrm{Sr}$ fluxes exported to the Atlantic Ocean. Earth and Planetary Science Letters, 274, 511-523.

Vinther, B.M., H.B. Clausen, D.A. Fisher, R.M. Koerner, S.J. 
Johnsen, K.K. Andersen, D. Dahl-Jensen, S.O. Rasmussen, J.P. Steffensen, and A.M. Svensson. 2008. Synchronizing ice cores from the Renland and Agassiz ice caps to the Greenland Ice Core Chronology. Journal of Geophysical Research, 113, D08115, doi:10.1029/ 2007JD009143.

Wang, X., Auler, A.S., Edwards, R.L., Cheng, H., Cristalli, P.S., Smart, P.L., Richards, D.A., and Shen, C.-C. 2004. Wet periods in northeastern Brazil over the past $210 \mathrm{Kyr}$ linked to distant climate anomalies. Nature, 432, 740-743. doi: 10.1038/nature03067.

Wang, X., Auler, A.S., Edwards, R.L., Cheng, H., Ito, E., Wang,Y., Kong, X., and Solheid, M. 2007. Millennial-scale precipitation changes in southern Brazil over the past 90,000 years. Geophysical Research Letters, 34, L23701. doi: 10.1029/2007GL031149.

Weldeab, S., Emeis, K.-C., HemLeben, C. and Siebel, W.
2002. Provenance of lithogenic surface sediments and pathways of riverine suspended matter in the Eastern Mediterranean Sea: evidence from $143 \mathrm{Nd} / 144 \mathrm{Nd}$ and 87Sr/86Sr ratios. Chemical Geology, 186, 139-149.

Yang, S.Y., Wei, G.J., Xia, X.P. Sun, M. and Tang, M. 2007. Provenance study of the late Cenozoic sediments in the Changjiang delta: REE and $\mathrm{Nd}$ isotopic constraints. Quaternary Sciences, 27, 339-346.

Zhang, Y., Chiessi, C.M., Mulitza, S., Zabel, M., Trindade, R.I.F., Hollanda, M.H.B.M., Dantas, E.L. Govin, A., Tiedemann, R. and Wefer, G. 2015. Origin of increased terrigenous supply to the NE South American continental margin during Heinrich Stadial 1 and the Younger Dryas. Earth and Planetary Science Letters, 432, 493-500.

Department of Geosciences University of Arizona, 28/02/2017, http://www.geo.arizona.edu.

Recibido: junio 2017

Revisado: diciembre 2017

Aceptado: febrero 2018

Publicado: diciembre 2018 